\title{
Article \\ Exendin-4 Promotes Schwann Cell Survival/Migration and Myelination In Vitro
}

\author{
Shizuka Takaku *, Masami Tsukamoto, Naoko Niimi, Hideji Yako (D) and Kazunori Sango (D) \\ Diabetic Neuropathy Project, Tokyo Metropolitan Institute of Medical Science, Tokyo 156-8506, Japan; \\ masami1022machida@gmail.com (M.T.); niimi-nk@igakuken.or.jp (N.N.); yako-hd@igakuken.or.jp (H.Y.); \\ sango-kz@igakuken.or.jp (K.S.) \\ * Correspondence: takaku-sz@igakuken.or.jp; Tel.: +81-3-6834-2359; Fax: +81-5316-3150
}

check for updates

Citation: Takaku, S.; Tsukamoto, M.; Niimi, N.; Yako, H.; Sango, K. Exendin-4 Promotes Schwann Cell Survival/Migration and Myelination In Vitro. Int. J. Mol. Sci. 2021, 22, 2971. https://doi.org/10.3390/ ijms22062971

Academic Editor: Claudio Grassi

Received: 28 December 2020

Accepted: 12 March 2021

Published: 15 March 2021

Publisher's Note: MDPI stays neutra with regard to jurisdictional claims in published maps and institutional affiliations.

Copyright: (c) 2021 by the authors. Licensee MDPI, Basel, Switzerland. This article is an open access article distributed under the terms and conditions of the Creative Commons Attribution (CC BY) license (https:// creativecommons.org/licenses/by/ $4.0 /)$

\begin{abstract}
Besides its insulinotropic actions on pancreatic $\beta$ cells, neuroprotective activities of glucagon-like peptide-1 (GLP-1) have attracted attention. The efficacy of a GLP-1 receptor (GLP-1R) agonist exendin-4 (Ex-4) for functional repair after sciatic nerve injury and amelioration of diabetic peripheral neuropathy (DPN) has been reported; however, the underlying mechanisms remain unclear. In this study, the bioactivities of Ex-4 on immortalized adult rat Schwann cells IFRS1 and adult rat dorsal root ganglion (DRG) neuron-IFRS1 co-culture system were investigated. Localization of GLP-1R in both DRG neurons and IFRS1 cells were confirmed using knockout-validated monoclonal Mab7F38 antibody. Treatment with 100 nM Ex-4 significantly enhanced survival/proliferation and migration of IFRS1 cells, as well as stimulated the movement of IFRS1 cells toward neurites emerging from DRG neuron cell bodies in the co-culture with the upregulation of myelin protein 22 and myelin protein zero. Because Ex-4 induced phosphorylation of serine/threonine-specific protein kinase AKT in these cells and its effects on DRG neurons and IFRS1 cells were attenuated by phosphatidyl inositol-3'-phosphate-kinase (PI3K) inhibitor LY294002, Ex-4 might act on both cells to activate PI3K/AKT signaling pathway, thereby promoting myelination in the co-culture. These findings imply the potential efficacy of Ex-4 toward DPN and other peripheral nerve lesions.
\end{abstract}

Keywords: glucagon-like peptide-1 receptor; exendin-4; IFRS1 Schwann cells; survival; migration; dorsal root ganglion neurons; co-culture; myelination; PI3 kinase signaling pathway

\section{Introduction}

Glucagon-like peptide-1 (GLP-1) is an incretin hormone secreted from intestinal L cells in response to the oral nutrient ingestion and exhibits insulinotropic actions by stimulating specific GLP-1 receptors (GLP-1Rs) on the pancreatic $\beta$ cells [1]. GLP-1 per se is rapidly degraded by dipeptidyl peptidase type 4 (DPP-4) into the biologically inactive peptide, whereas GLP-1R agonists, such as albiglutide, dulaglutide, exenatide (exendin-4 (Ex-4)), liraglutide, lixisenatide, semaglutide, and taspoglutide, show a substantially longer plasma half-life than GLP-1 because of their resistance to DPP-4. These GLP-1R agonists are currently utilized for the treatment of patients with type 2 diabetes [2]. GLP-1Rs are localized at not only the pancreas but also the extra-pancreatic tissues, including the nervous system [3]. In addition to the inhibition of appetite and food intake, neurotrophic and neuroprotective properties of GLP-1R agonists have been receiving increasing attention. A large number of animal studies have suggested the efficacy of GLP-1R agonists, particularly Ex-4 and liraglutide, for the prevention and restoration of Parkinson's disease, Alzheimer's disease, stroke, and other neurodegenerative disorders [4]. According to a recent clinical study [5], Ex-4 ameliorated the severity of motor symptoms associated with Parkinson's disease. The neuroprotective activities of GLP-1R agonists following axonal injury and in peripheral neuropathies have also been documented [6-8]. Himeno et al. [9] reported that Ex-4 restored the decreases in motor nerve conduction velocities and other neurological abnormalities of streptozotocin (STZ)-induced diabetic mice without normalizing blood 
glucose levels. These findings provide further evidence of the direct actions of Ex-4 on the peripheral nervous system; however, the underlying mechanisms remain largely unclear.

In our previous study [10], Ex-4 dose-dependently $(1 \mathrm{nM}<10 \mathrm{nM}<100 \mathrm{nM})$ enhanced neurite outgrowth and survival of adult rat dorsal root ganglion (DRG) neurons, and these effects were attenuated by co-treatment with phosphatidylinositol-3' phosphate kinase (PI3K) inhibitor LY294002. In addition, pre-treatment with LY294002 abolished Ex-4-induced suppression of the activity of RhoA, an inhibitory molecule of axonal regeneration and neuronal survival [11]. These findings imply that Ex-4 promotes neurite outgrowth and survival of DRG neurons through the activation of PI3K signaling pathway, which negatively regulates RhoA activity. However, direct evidence that Ex-4 activates PI3K pathway in DRG neurons has not been provided. It also remains unknown if GLP-1R agonists act on Schwann cells to promote axonal regeneration and remyelination after injury or protect neurons against diabetic and other peripheral neuropathies. Liu et al. [6] suggested anti-apoptotic effects of Ex-4 toward Schwann cells in STZ-diabetic rats, but the bioactivities of Ex-4 on cultured Schwann cells have not been fully examined. We have established a spontaneously immortalized Schwann cell line IFRS1 from long-term culture of adult Fischer 344 rat peripheral nerves $[12,13]$. IFRS1 cells display distinct Schwann cell phenotypes, such as spindle-shaped morphology with intense immunoreactivity for glial cell markers, synthesis and secretion of neurotrophic factors, and fundamental ability to myelinate neurites in co-culture with adult rat DRG neurons [12], NGF-primed PC12 cells [14], NSC-34 mouse neuroblastoma/embryonic spinal motor neuron hybrid cells $[15,16]$ and ND7 / 23 mouse neuroblastoma/rat embryonic DRG neuron hybrid cells [17] (Takaku et al., in preparation). In addition, we have recently introduced assay systems to evaluate the survival/proliferation and migration of IFRS1 cells [18]. The present study is aimed at elucidating the neuroprotective actions of Ex-4 on cultured rat DRG neurons and IFRS1 Schwann cells. First, we identified GLP-1R on DRG neurons and IFRS1 cells using a well-characterized and verified antibody, then investigated the effects of exogenous Ex-4 on survival/proliferation and migration of IFRS1 cells, and myelination in the DRG neuron-IFRS1 co-culture system.

\section{Results}

\subsection{GLP-1R mRNA and Protein Expression in Neurons and IFRS1 Schwann Cells}

Prior to the evaluation of Ex-4 bioactivities on neurons and Schwann cells, the expression and localization of GLP-1R at these cells should be confirmed. For that purpose, we conducted RT-PCR, Western blot and immunocytochemical analyses. Because much smaller amount of RNA and protein was obtained from primary cultured DRG neurons as compared with the lined cells, it was difficult to perform real-time RT-PCR or quantitative Western blotting using these samples. RT-PCR analysis showed mRNA expression of GLP-1R and glyceraldehyde-3-phosphate dehydrogenase (GAPDH; a housekeeping gene used for confirmation of the proper reactions) in DRG neurons and IFRS1 cells, as well as NSC-34 cells [15] and ND7/23 mouse neuroblastoma/rat embryonic DRG neuron hybrid cells [18] (Figure 1a). These finding imply that these cells synthesize GLP-1R. Western blot analysis and immunofluorescence using knockout-validated antibody Mab7F38 [19] resulted in GLP-1R expression in both DRG neurons and IFRS1 Schwann cells, as well as NSC-34 and ND7 / 23 cells (Figure 1b,c). 
(a)

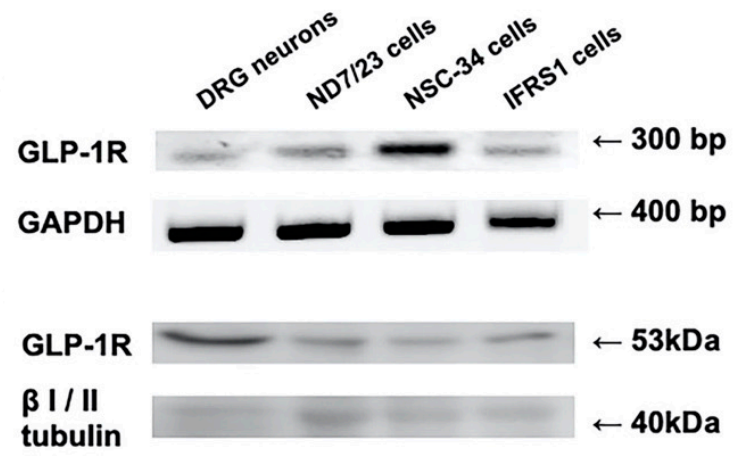

(c)

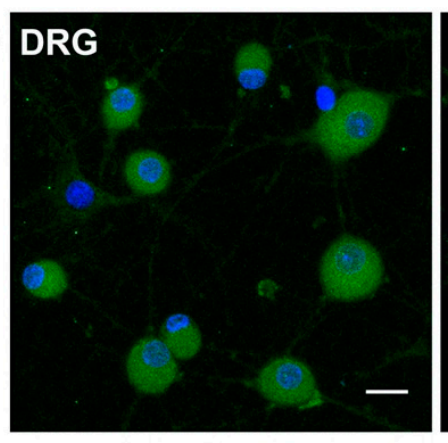

Figure 1. Glucagon-like peptide-1 (GLP-1R) mRNA and protein expression in primary cultured dorsal root ganglion (DRG) neurons, NSC-34 and ND7/23 neuronal cell lines, and an IFRS1 Schwann cell line. (a) GLP-1R and glyceraldehyde-3phosphate dehydrogenase (GAPDH) mRNA expression in the 4 kinds of cells; RT-PCR analysis. (b) GLP-1R and $\beta I / I I$ tubulin (a house-keeping protein used for confirmation of the proper reactions) expression in the 4 kinds of cells; Western blot analysis. (c) GLP-1R immunoreactivity in DRG neurons and IFRS1 cells; immunofluorescence. Nuclei are stained blue with 4',6-diamidino-2-phenylindole (DAPI). Scale bars indicate $20 \mu \mathrm{m}$.

\subsection{Ex-4 Induces AKT Phosphorylation in ND7/23 and IFRS1 Cells}

In our previous study [10], Ex-4 dose-dependently $(1 \mathrm{nM}<10 \mathrm{nM}<100 \mathrm{nM})$ promoted neurite outgrowth and survival of DRG neurons, and these effects were attenuated by co-treatment with a PI3K inhibitor LY294002 $(5 \mu \mathrm{M}$ and $25 \mu \mathrm{M})$. We tried to examine phosphorylated state of serine/threonine-specific protein kinase AKT, a key molecule of PI3K signaling pathway in DRG neurons in the presence or absence of Ex-4; however, the amount of protein obtained from the primary cultured DRG neurons was insufficient to conduct Western blotting. We then substituted them with ND7/ 23 cells, which possess high proliferative activity and retain some characteristic features of DRG neurons $[17,18,20]$. In addition to ND7 / 23 cells, the effects of Ex-4 on PI3K signaling in IFRS1 Schwann cells were investigated. Treatment with $100 \mathrm{nM} \mathrm{Ex}-4$ for $60 \mathrm{~min}$ significantly upregulated expression of phosphorylated AKT (p-AKT) in both ND7/23 and IFRS1 cells (Figure 2). These findings corroborate our previous study with DRG neurons [10] and suggest the bioactivities of Ex-4 on the neurons and Schwann cells via PI3K/AKT signaling.

\subsection{Ex-4 Enhances Survival/Proliferation and Migration of IFRS1 Schwann Cells}

Because the beneficial effects of Ex-4 on primary cultured and lined DRG neurons have already been documented $[9,10,21]$, the following experiments were conducted with a focus on its bioactivities toward IFRS1 Schwann cells [18]. MTS assays revealed that the values of absorbance at 3 and 6 days of incubation were significantly upregulated by $10 \mathrm{nM}$ and $100 \mathrm{nM}$ Ex-4 (Figure 3a). Scratch wound assays revealed that the number of migrating IFRS1 cells in the $100 \mathrm{nM} \mathrm{Ex}$-4-treated group was significantly higher than that in the control group (Figure 4). However, these Ex-4 effects were attenuated by co-treatment with $25 \mu \mathrm{M}$ LY294002 (Figures 3b and 4). These findings together with the Ex-4-induced AKT phosphorylation (Figure 2b) suggest that Ex-4 can enhance the survival/proliferation and migration of IFRS1 cells via activating PI3K/AKT signaling pathway. 
(a)
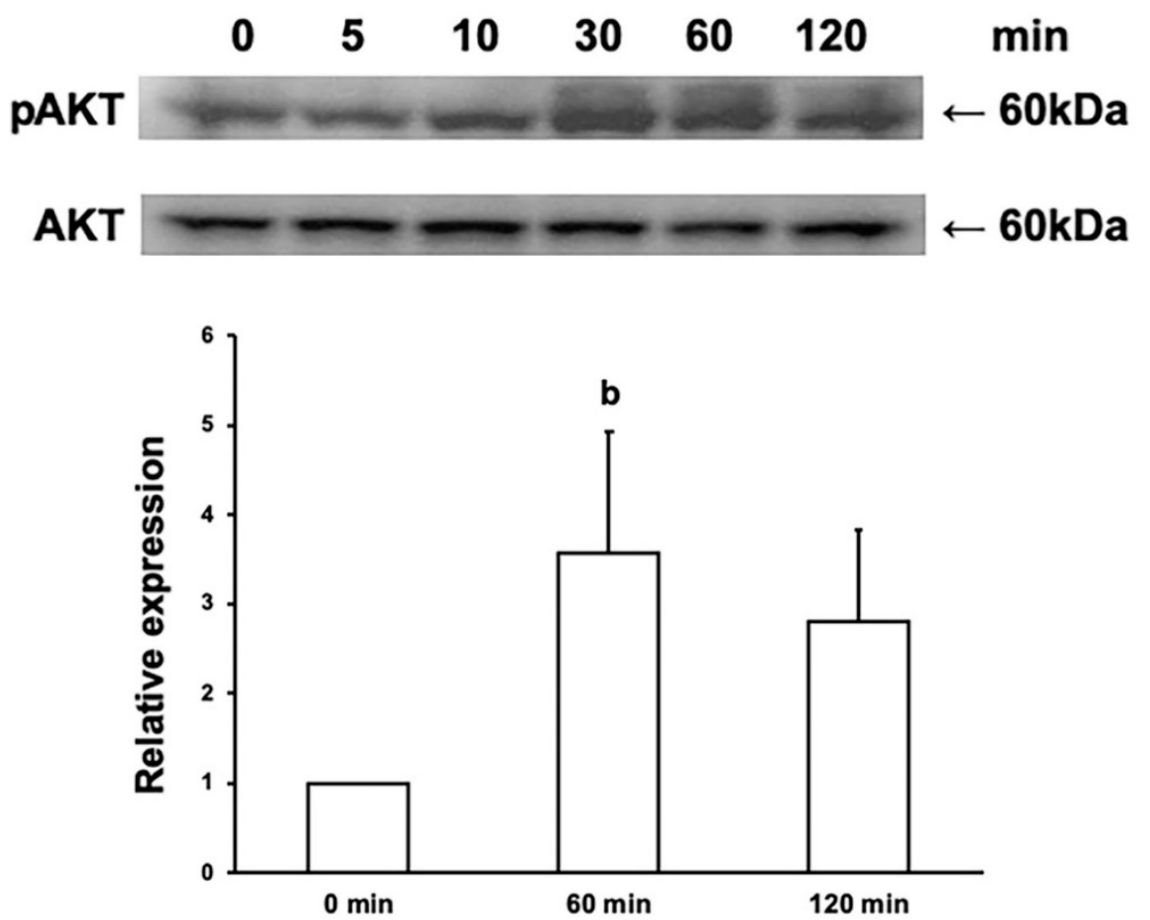

(b)

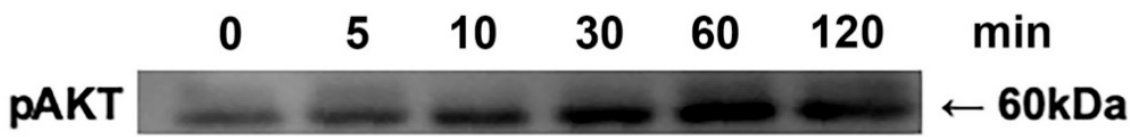

AKT $\leftarrow 60 \mathrm{kDa}$

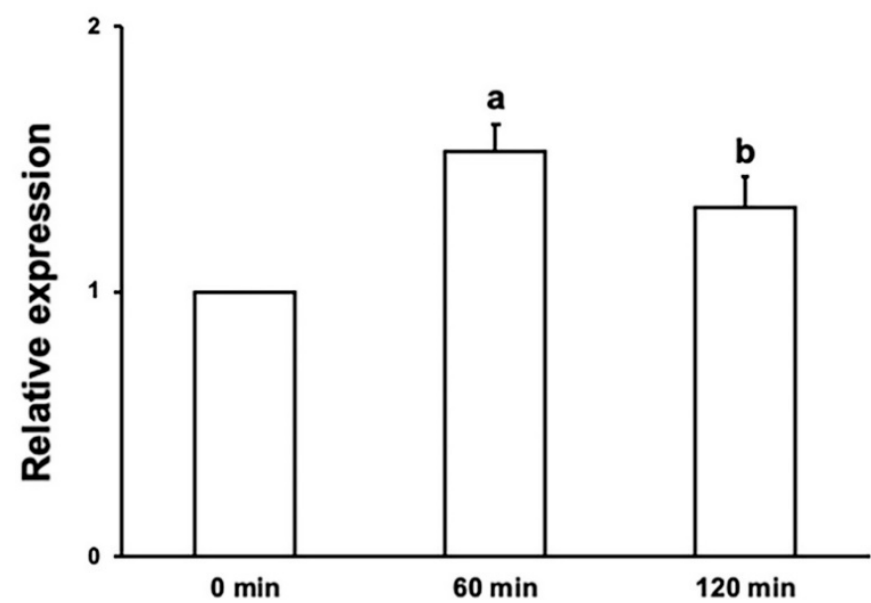

Figure 2. Treatment with $100 \mathrm{nM}$ exendin-4 (Ex-4) induces phosphorylation of serine/threonine-specific protein kinase AKT in ND7/23 cells (a) and IFRS1 cells (b). The representative pictures of the Western blot analysis (upper) and quantitative data (relative phosphorylated AKT (p-AKT) expression at 0, 60, and 120 min after Ex-4 treatment; lower) are shown. Values represent means $+\mathrm{SD}$ from 3 experiments. a: $p<0.01$ as compared with $0 \mathrm{~min}$, b: $p<0.05$ as compared with 0 min. 
(a)

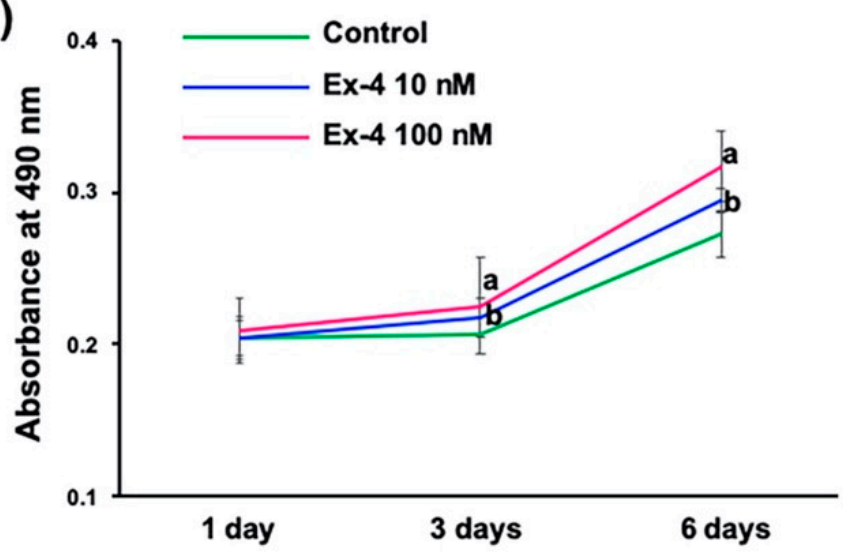

(b)

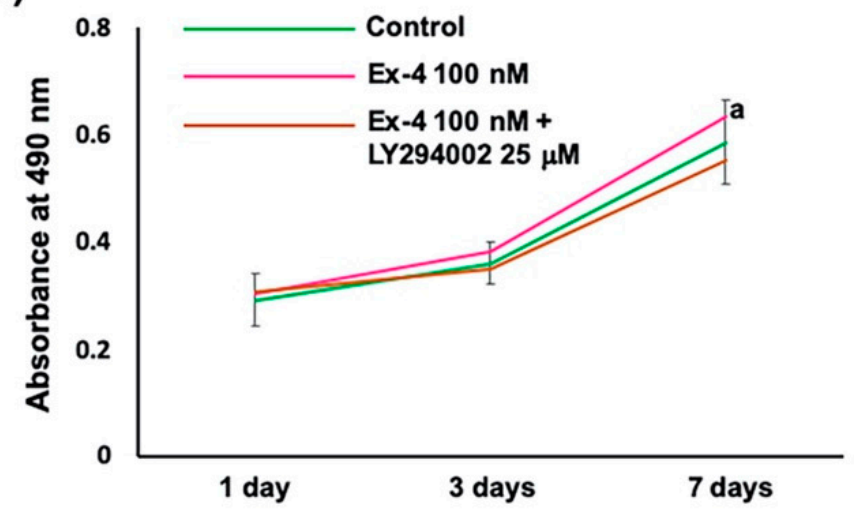

Figure 3. Ex-4 promotes survival/proliferation of IFRS1 cells; MTS assay. (a) The absorbance at 1, 3, and 6 days after

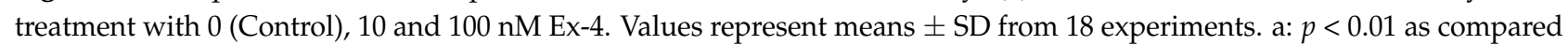
with Control, b: $p<0.05$ as compared with Control. (b) The absorbance at 1, 3, and 7 days after treatment with 0 (Control) and $100 \mathrm{nM}$ Ex-4 in the presence or absence of $25 \mu \mathrm{M}$ LY294002. Values represent means \pm SD from 18 experiments. a: $p<0.01$ as compared with Control and Ex-4 $100 \mathrm{nM}+\mathrm{LY} 29400225 \mu \mathrm{M}$.

(a)

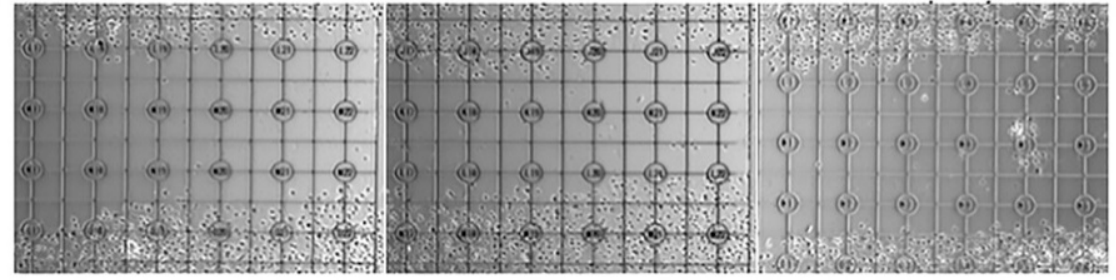

Control

(b)

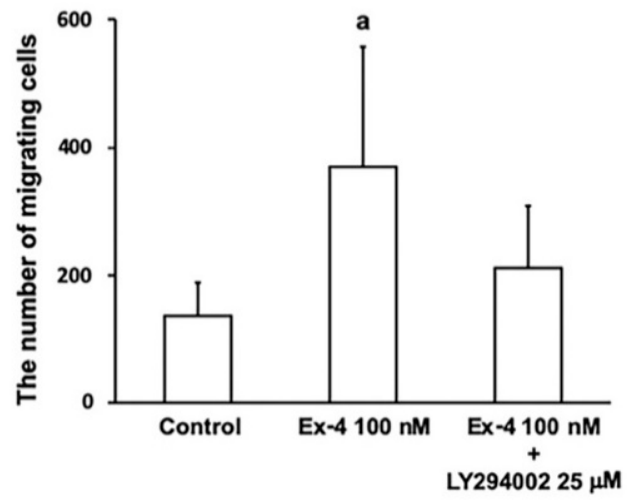

Ex-4 $100 \mathrm{nM}+$ LY294002 $25 \mu \mathrm{M}$

Figure 4. Ex-4 promotes migration of IFRS1 cells; scratch wound assay. (a) Representative photomicrographs of IFRS1 cells at 1 day after scratch. (b) The number of migrating cells at 1 day after treatment with 0 (Control) and $100 \mathrm{nM}$ Ex-4 in the presence or absence of $25 \mu \mathrm{M}$ LY294002. Values represent means $+\mathrm{SD}$ from 24 experiments. a: $p<0.01$ as compared with Control and Ex-4 $100 \mathrm{nM}+$ LY294002 $25 \mu \mathrm{M}$. 


\subsection{Ex-4 Stimulates Myelination in DRG Neuron-IFRS1 Co-Culture System}

Ex-4 accelerated DRG neuronal cell survival and neurite outgrowth [10] and Schwann cell survival and migration (Figures 3 and 4). These findings together with the previous in vivo study [7] led us to expect Ex-4's positive effects on myelination in DRG neuron-IFRS1 co-culture system [12,13]. DRG neurons were maintained for a week in a serum-free culture medium with the mixture of neurotrophic factors $(10 \mathrm{ng} / \mathrm{mL}$ of nerve growth factor (NGF), glial cell line-derived neurotrophic factor (GDNF), and ciliary neurotrophic factor (CNTF)) to promote neurite outgrowth. The neurons were then co-cultured with IFRS1 Schwann cells and maintained for up to 3 weeks under serum-free culture conditions in the presence or absence of $10 \mathrm{nM}$ or $100 \mathrm{nM}$ Ex-4 (Figure 5a). Phase-contrast micrographs at 14 days of co-culture (Figure 5b) showed increased cell-free area among neurite bundles in Ex-4-treated cells compared with Control, suggesting that Ex-4 accelerated the migration of IFRS1 cells toward the neurites emerging from DRG neurons. Immunocytochemistry conducted at 21 days of co-culture indicate that Ex-4 increased the immunoreactivity to peripheral myelin protein (PMP) 22 (green) in IFRS1 cells surrounding $\beta I I I$ tubulin-immunoreactive DRG neurites (red) (Figure 5c). For the quantitative analysis, we counted the number of PMP22-immunoreactive IFRS1 cells attached to a neurite in each photomicrograph, in a similar manner to our previous study [22]. The average number of IFRS1 cells attached to a neurite is $2.4 \pm 0.9$ in Control and $3.3 \pm 0.8$ in $100 \mathrm{nM} \mathrm{Ex}-4$ ( $\mathrm{n} \geq 9$ neurites from 3 co-culture samples); the latter is significantly higher than the former $(p<0.05)$ (Figure 5d). Consistent with these findings, Western blot analysis revealed that Ex-4 significantly upregulated the expression of PMP22 and myelin protein zero (MPZ) at 21 days of co-culture (Figure 5e). Furthermore, Ex-4-induced AKT phosphorylation at 2 days of co-culture (Figure $5 \mathrm{f}$ ) agrees with the involvement of PI3K/AKT signaling pathway in the stimulatory effects of Ex-4 toward both DRG neurons [10] and IFRS1 cells (Figures 2 and 3). 
(a)

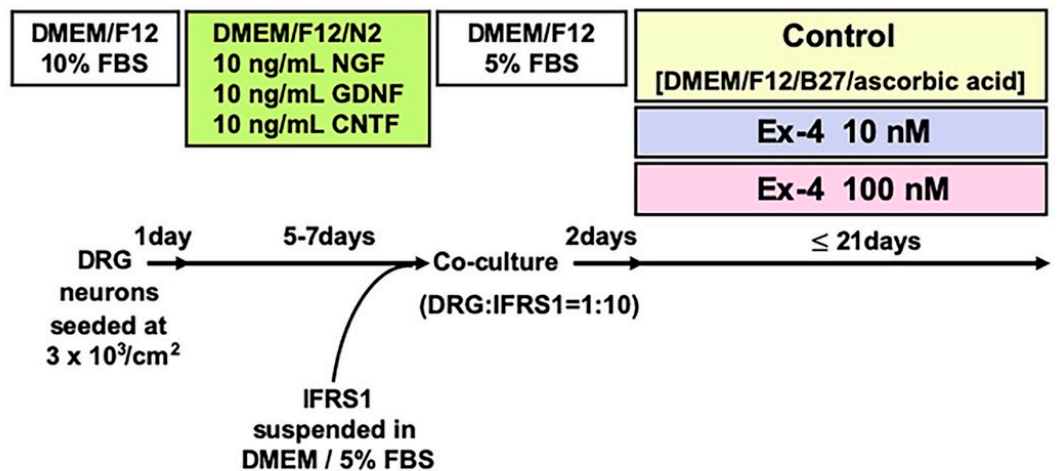

(b)

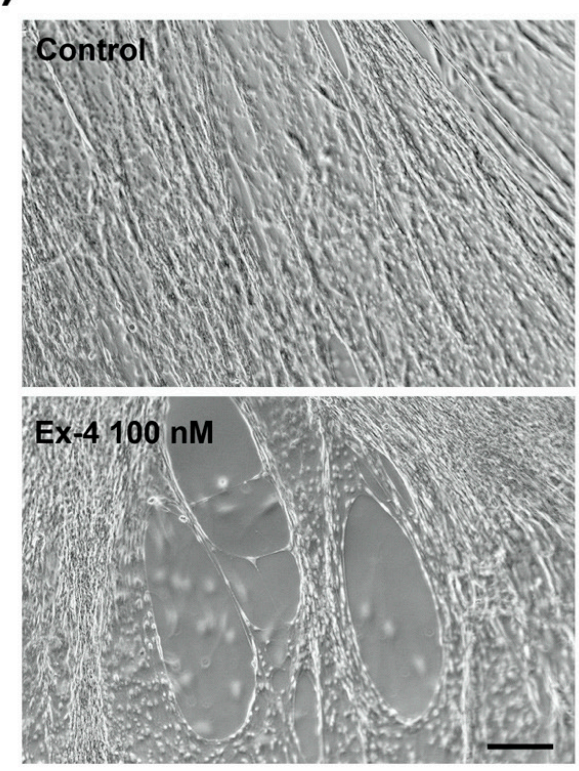

(c)
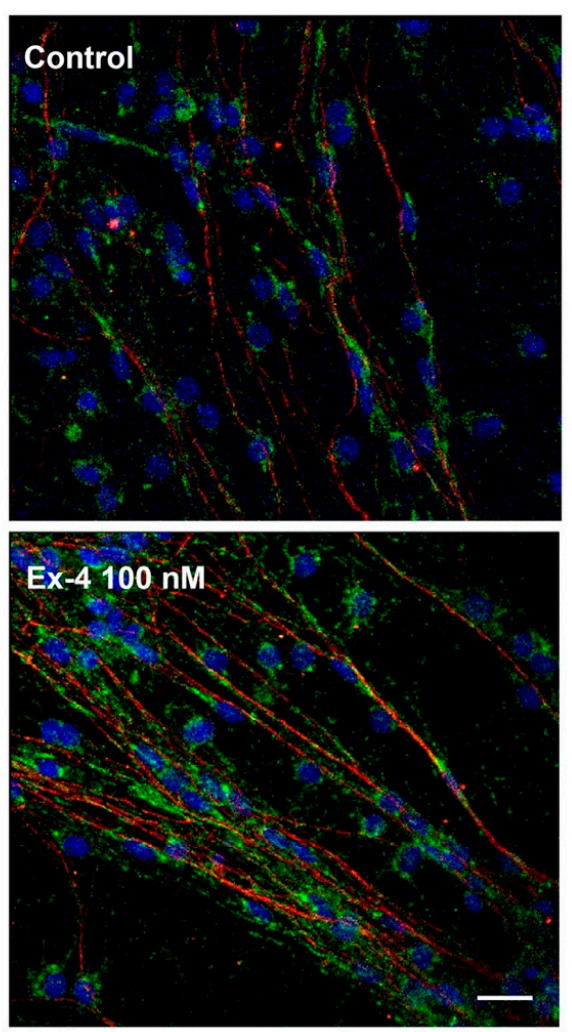

(d)
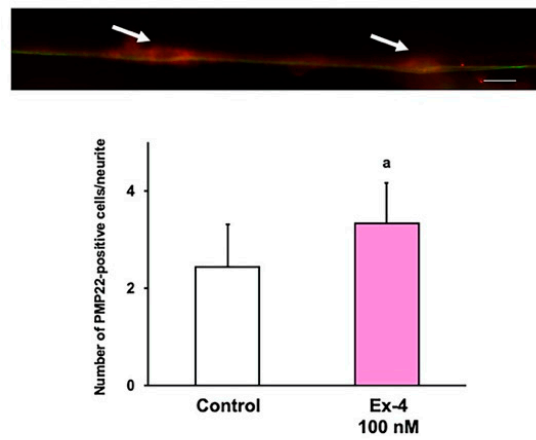

Figure 5. Cont. 


\section{(e)}
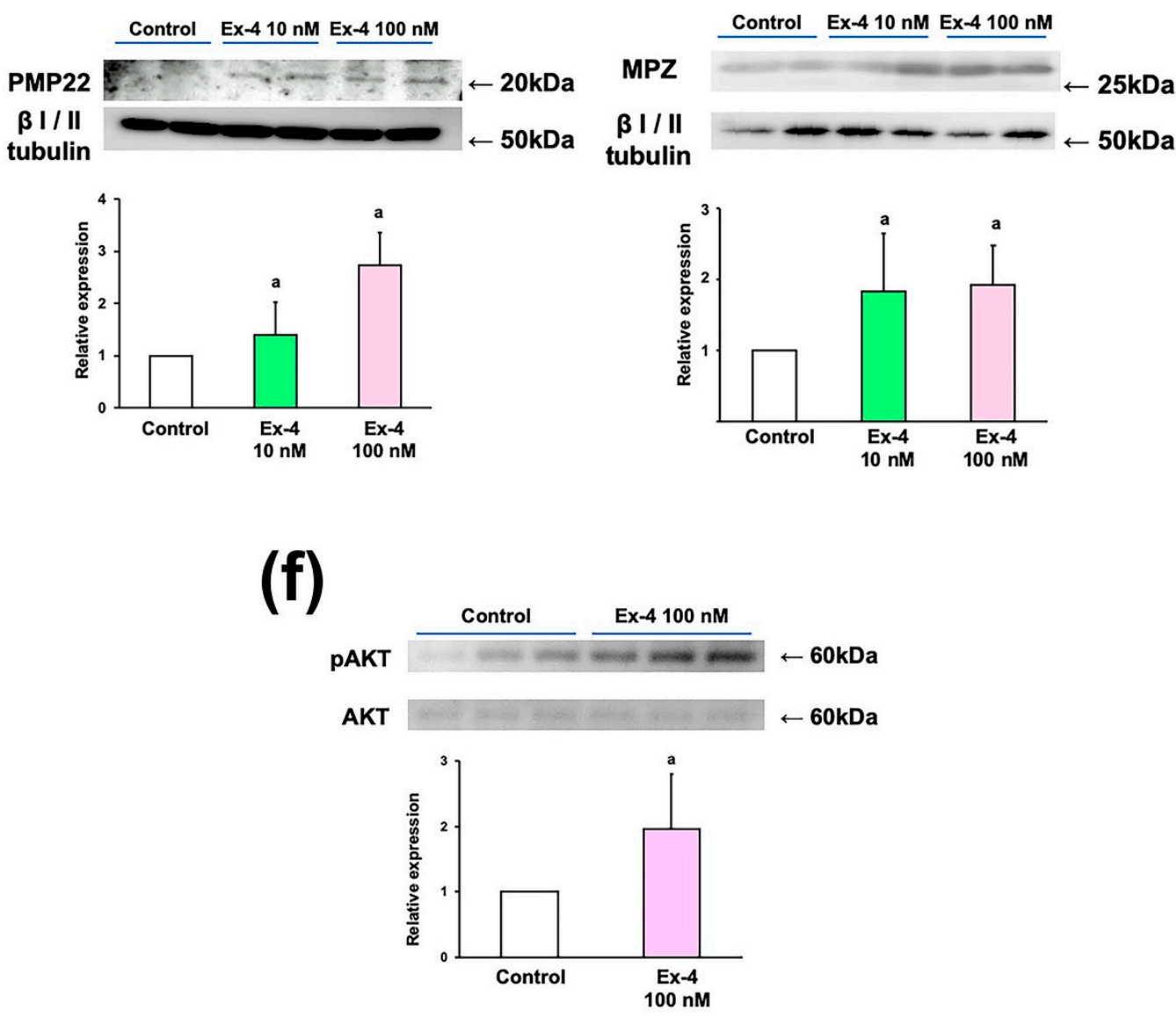

Figure 5. Ex-4 stimulates myelination in DRG neuron-IFRS1 co-culture system. (a) Schematic representation of the standard procedure for the co-culture of adult rat DRG neurons and IFRS1 cells. (b) Representative phase-contrast photomicrographs at 14 days of co-culture in the presence or absence of $100 \mathrm{nM} \mathrm{Ex-4}$. Scale bar indicates $100 \mu \mathrm{m}$. (c) Representative immunofluorescence photomicrographs at 21 days of co-culture in the presence or absence of $100 \mathrm{nM}$ Ex-4. Ex-4 increased the immunoreactivity to rabbit anti-peripheral myelin protein 22 (PMP22) (green) in IFRS1 cells surrounding $\beta$ III tubulinimmunoreactive DRG neurites (red). Scale bar indicates $20 \mu \mathrm{m}$. (d) A representative immunofluorescence photomicrograph at 21 days of co-culture (upper) shows two PMP-immunoreactive cells (arrows) attached to a $\beta I I I$ tubulin-immunoreactive neurite. Scale bar indicates $10 \mu \mathrm{m}$. Ex-4 increases PMP22-immunoreactive IFRS1 cells attached to a neurite (lower). Values represent means $+\mathrm{SD}$ from 9 to 16 experiments. a: $p<0.05$ as compared with Control. (e) Ex-4 upregulates expression of myelin proteins PMP22 and MPZ at 21 days of co-culture; Western blot analysis. Values represent means + SD from 3 to 6 experiments. a: $p<0.05$ as compared with Control. (f) Ex-4 induces phosphorylation of AKT at 2 days of co-culture; Western blot analysis. Values (relative p-AKT expression) represent means + SD from 6 experiments. a: $p<0.05$ as compared with Control.

\section{Discussion}

Neuroprotective properties of Ex-4 [6-10] have suggested its therapeutic potential toward DPN independent of the blood glucose-lowering effects [4]. Because neurons and Schwann cells are major constituents of the peripheral nervous system, the present study is focusing on the biological activities of Ex-4 on these cells with possible action mechanisms. Considering that some characteristic features of DRG neurons and Schwann cells change with maturation and aging, these cells obtained from adult animals appear to be better tools than those from embryonic or neonatal animals for the study of DPN and other peripheral nerve lesions $[13,23]$. The primary culture of DRG neurons from 
mature rodents have been widely utilized for morphological analyses (for example, in situ hybridization, immunocytochemistry, and electron microscopy) and functional assays (for example, neurite outgrowth, survival, calcium imaging, and electrophysiology). However, the yield of neurons obtained from a single animal is insufficient for conducting quantitative molecular and biochemical analyses (for example, real-time RT-PCR, Western blotting, and enzyme-linked immunosorbent assay), and sacrificing a large number of animals for the quantitative studies is ethically problematic. We then substituted them with ND7/23 cells to perform Western blotting, as mentioned above. The primary culture of adult rodent Schwann cells has been established, but it needs a time-consuming process to get good yields of Schwann cells with high purity from the connective tissue-enriched mature peripheral nerves $[23,24]$. Although growth stimulants such as forskolin and neuregulin- $1 \beta$ are employed for the passage of IFRS1 cells, they possess proliferative activity feasible for the molecular and biochemical analyses, as well as characteristic features of Schwann cells [12-14,16]. In addition to IFRS1 cells in this study, Ex-4 has been shown to enhance proliferation/survival and migration of primary cultured Schwann cells [25] and immortalized mouse Schwann cells 1970C3 [26] (Figure S1). These findings suggest the Ex-4's stimulatory effects on Schwann cells regardless of cell types (primary or lines) and lines. Numerous Schwann cell lines have been established by us and others, but only a few of them, including IFRS1 cells, have shown the capability to form myelin structure under co-culture with neuronal cells [13,27]. In particular, our DRG neuronIFRS1 co-culture system can be stably and effectively used for exploring neuron-Schwann cell interplay during axonal degeneration and regeneration, as well as pathogenesis of demyelinating neuropathies [22].

The existence of GLP-1R in DRG neurons and IFRS1 cells is the prerequisite for investigating the biological activities of Ex-4 on these cells. Although the previous studies indicated GLP-1R immunoreactivity in DRG neurons and Schwann cells in vivo and in vitro $[9,10]$, the specificity of the GLP-1R antibodies employed in those studies has not been verified. Our RT-PCR analysis resulted in GLP-1R mRNA expression in primary cultured DRG neurons and IFRS1 cells, as well as NSC-34 and ND7/23 neuronal cell lines (Figure 1a). The Western blot analysis using knockout-validated monoclonal Mab7F38 antibody [18] confirmed localization of GLP-1R at these cells (Figure 1b). The immunofluorescent micrographs (Figure 1c) indicate ubiquitous distribution of GLP-1R at both cytoplasm and cell membrane rather than cell surface-predominant expression in both DRG neurons and IFRS1 cells. Similarly, GLP-1R immunoreactivity throughout the cytoplasm of murine pancreatic acinar cells was detected by the same antibody [19].

Ex-4-induced AKT phosphorylation in both ND7/23 and IFRS1 cells (Figure 2) and the attenuation of its stimulatory effects on DRG neurons [10] and IFRS1 cells by cotreatment with a PI3K inhibitor LY294002 (Figures 3 and 4) suggest the involvement of PI3K/AKT signaling pathway in its bioactivities toward these cells. Consistent with these findings, GLP-1R agonists alleviated neuronal cell death after subarachnoid hemorrhage in rats [28] and methylglyoxal- and $\beta$-amyloid-induced neurotoxicity $[29,30]$ via GLP$1 \mathrm{R} / \mathrm{PI} 3 \mathrm{~K} / \mathrm{AKT}$ axis. In the previous studies using DRG neurons [10] and SH-SY5Y and PC12 cells [31], neurotrophic and neuroprotective actions of Ex-4 can be, at least partially, attributable to the suppression of RhoA, an inhibitory molecule of axonal regeneration [32], through PI3K/AKT pathway. The downstream target molecules of PI3K pathway, such as GSK3 $\beta$ and mTOR, may also be related to the neuroprotective function of GLP-1R agonists [33,34]. In addition to those studies targeted at neurons, restoring effects of Ex-4 against decreased myelinated nerve fiber size and Schwann cell apoptosis in STZ-diabetic rats have been documented [6]; however, direct actions of Ex-4 and other GLP-1R agonists toward Schwann cells with possible mechanisms remain unclear. Like Ex-4 in this study, several molecules have been shown to promote Schwann cell viability/proliferation and migration through PI3K/AKT pathway [35-37]. Thus, this pathway appears to play a key role in the neuroprotective properties of Schwann cells in response to peripheral nerve lesions. In a recent study by Pan et al. [25], Ex-4 enhanced Schwann cell proliferation and 
migration through activating JAK/STAT pathway in vitro. Although we have not examined whether JAK/STAT pathway is involved in the Ex-4's stimulatory effects on IFRS1 cells, Ex4 and other GLP-1R agonists are likely to exert their neuroprotective actions via activating multiple signaling pathways. For instance, stimulatory effects of Ex-4 on rat colonic myenteric neurons are dependent on activation of PI3K and mitogen-activated protein kinase (MEK/ERK) signaling cascades [38]. Our future studies using IFRS1 cells will focus on the interrelationship between PI3K/AKT, MEK/ERK, and JAK/STAT pathways regarding the neuroprotective function of Ex-4. Which pathways are more involved in Schwann cell survival/proliferation and/or migration may also be an important issue to be solved. Our previous study using DRG neurons suggest the involvement of the above 3 signaling pathways in CNTF-induced neurite outgrowth, whereas PI3K/AKT and JAK/STAT pathways are thought to play major roles in mediating the survival response of neurons to CNTF [39].

The findings from the co-culture system (Figure 5) imply that Ex-4 can accelerate the myelination process, and support the previous studies addressing Ex-4-induced axonal regeneration and remyelination in rats following sciatic nerve crush injury [7]. Although our trials to detect nodal structures in the co-culture have not been successful, we had verified the formation of myelin sheaths by Sudan black B staining and electron microscopy $[12,13]$. In addition, double immunofluorescence (MPZ or PMP22/ $\beta$ III tubulin) combined with $X$-Gal staining on the co-cultures of DRG neurons and $\beta$-galactosidase gene-inserted IFRS1 cells revealed co-localization of the X-Gal stain with the myelin protein expression. By electron microscopy, the X-Gal stained IFRS1 cells showed cytoplasm with granular electron-dense precipitate and a myelin sheath [12]. Based on these findings, it seems appropriate to provide quantitative data of myelin sheath formation using double immunofluorescence (Figure 5c,d) [22]. The morphological evidence is further supported by Ex-4-induced upregulation of PMP22 and MPZ protein expression (Figure 5e). Because the beneficial effects of Ex-4 on DRG neurons and IFRS1 cells were abolished by the PI3K inhibitor, Ex-4 might act on both cells to accelerate myelination through PI3K/AKT signaling pathway. In addition, Ex-4-induced AKT phosphorylation at 2 days of co-culture (Figure 5f) agrees with the previous study, which suggested that intracellular signals mediated by PI3K / AKT are crucial for initiation of myelination [40,41]. However, there is room for further investigation to safely state that AKT signaling pathway activated by Ex-4 in both cells play a major role in myelination in the co-culture system. In addition to the analyses using the PI3K inhibitor, we plan to manipulate GLP-1R and AKT genes in either DRG neurons or IFRS1 Schwann cells. Because impaired axonal regeneration and remyelination are one of the characteristic features in pathophysiology of DPN [42], therapeutic approaches of Ex-4 toward DPN can be expected. Sheknova et al. [43] recently reported that treatment of STZ-diabetic rats with arginine-rich Ex-4 ameliorated neuropathic pain, as well as reduced myelinated nerve fiber diameters and myelin basic protein expression in sciatic nerves. Our in vitro studies combined with that in vivo study suggest the efficacy of Ex-4 for ameliorating the loss of myelinated fibers in DPN. Using the same co-culture system, we have observed myelination-promoting activities of GDNF [12] and CNTF [13]. The efficacy of these neurotrophic factors for axonal regeneration after injury and amelioration of DPN have been shown in animal models [44]; however, the clinical trials using them thus far revealed unsuccessful or incomplete [45]. In contrast, Ex-4 has been approved as a safe and effective anti-diabetic agent [2] and its repurposing for patients with Parkinson's diseases is an ongoing project $[5,46]$. Although the clinical trials of Ex-4 and other GLP-1 mimetics targeted at patients with DPN have not gained significant outcomes [47,48], elucidating their precise action mechanisms will help advance the therapeutic strategies.

The beneficial effects of Ex-4 on DRG neurons, IFRS1 Schwann cells, and their coculture system in our previous [10] and present studies are schematically represented in Figure 6. Although further analyses are needed to strengthen our hypothesis, these findings imply their efficacy for the prevention and restoration of DPN and other PNS lesions. 


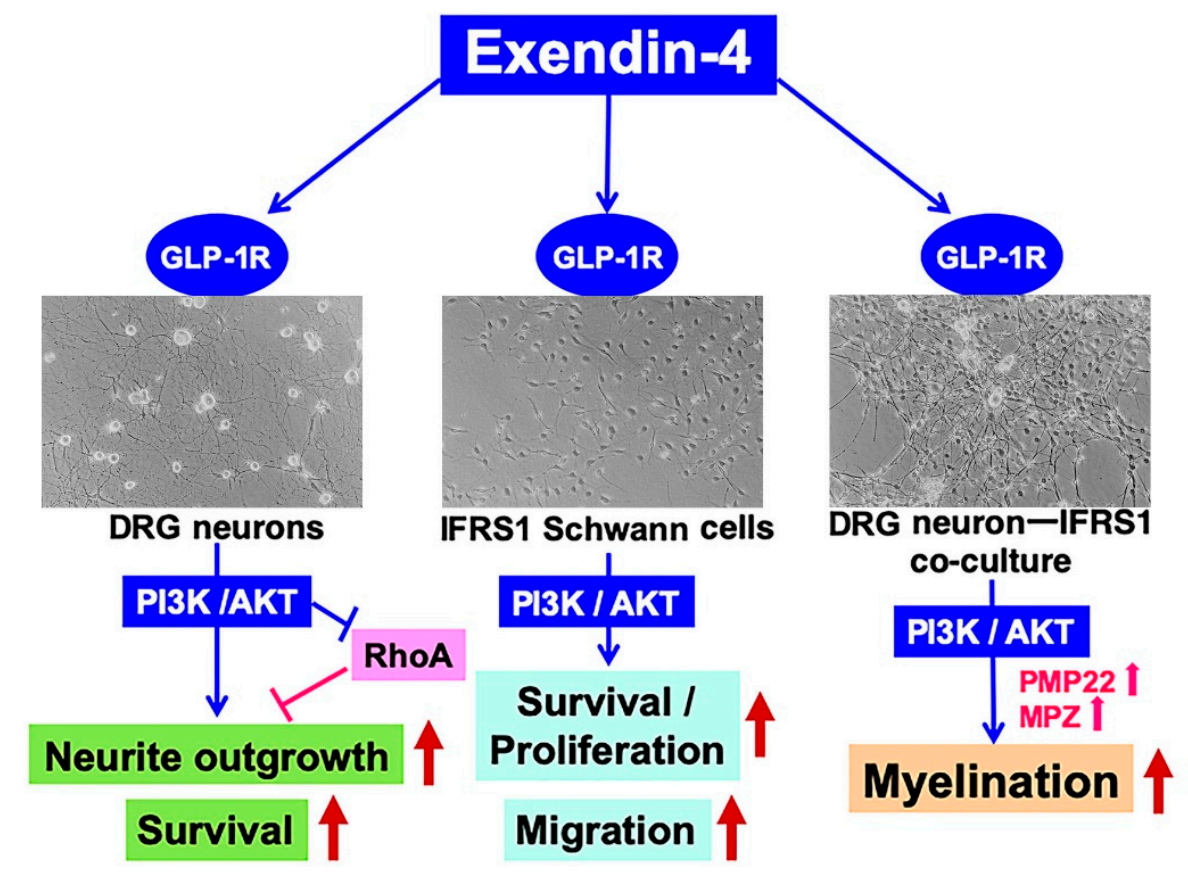

Figure 6. Schematic representation of possible mechanisms for the beneficial effects of Ex-4 on DRG neurons, IFRS1 Schwann cells, and their co-culture system.

\section{Materials and Methods}

\subsection{Animals}

Six-week-old female Wistar rats were obtained from CLEA Japan, Inc. (Shizuoka, Japan). All rats received humane care and handling in accordance with the Guidelines of the Care and Use of Animals (Tokyo Metropolitan Institute of Medical Science, 2011; institutional approval number 20-016). Prior to the dissection, rats were anesthetized for euthanasia with $3 \%$ isofluorane (Abbott Japan, Tokyo, Japan) for $3 \mathrm{~min}$.

\subsection{Isolation and Culture of DRG Neurons}

Dissociated cell culture of DRG neurons was performed as previously reported method [10,18]. Briefly, DRG from the cervical to the lumbar level were dissected from each animal and dissociated with collagenase (CLS-3; Worthington Biochemicals, Freehold, NJ, USA) and trypsin (Sigma, St. Louis, MO, USA). These ganglia were subjected to density gradient centrifugation (5 min, $200 \mathrm{~g}$ ) with $30 \%$ Percoll PLUS ${ }^{\mathrm{TM}}$ (GE Healthcare Bio-Sciences Corp., Piscataway, NJ, USA) to eliminate the myelin sheath. This procedure resulted in a yield of more than $5 \times 10^{4}$ neurons along with a smaller number of non-neuronal cells. These neurons were suspended in Dulbecco's Modified Eagle's medium (DMEM)/Ham's F12 (Thermo Fisher Scientific Inc., Waltham, MA, USA) supplemented with 10\% fetal bovine serum (FBS; Thermo Fisher Scientific Inc., Waltham, MA, USA) and employed for Western blot and immunocytochemical analyses and co-culture with IFRS1 Schwann cells.

\subsection{Culture of IFRS1 Schwann Cells, NSC-34 Motor Neuron-Like Cells, and ND7/23 Sensory Neuron-Like Cells}

IFRS1 Schwann cells were established in our laboratory [12]. IFRS1 cells at the passage of 30-40 were maintained in DMEM (Thermo Fisher Scientific Inc., Waltham, MA, USA) supplemented with 5\% FBS; and employed for Western blot and immunocytochemical analyses, proliferation/survival, and migration assays; and co-culture with DRG neurons. NSC-34 cells [15] and ND7/23 cells [17] were kindly provided by Kazuhiko Watabe of Kyorin University, and Atsufumi Kawabata of Kindai University, respectively. These cells at the passage of 15-20 were maintained in DMEM supplemented with 5\% FBS and employed for Western blot analysis. 


\subsection{Proliferation/Survival Assay for IFRS1 Cells}

The effects of Ex-4 on the proliferation/survival of IFRS1 cells were evaluated using the CellTiter $96^{\circledR}$ Aqueous One Solution Cell Proliferation Assay kit (Promega Corp., Madison, WI, USA), as previously reported [18]. The cells were seeded onto each well of 96-well culture plates at an approximate density of $3 \times 10^{4} / \mathrm{cm}^{2}$ and were incubated overnight in DMEM supplemented with 5\% FBS. The cells were then maintained in DMEM/1\% FBS with different concentrations $(0,10$, or $100 \mu \mathrm{M})$ of Ex-4 (R\&D Systems, Inc., Minneapolis, MN, USA) for 1, 3, and 6 days. After rinsing with $250 \mu \mathrm{L}$ of DMEM, the cells were incubated for $1 \mathrm{~h}$ at $37^{\circ} \mathrm{C}$ in $100 \mu \mathrm{L}$ of DMEM with $10 \mu \mathrm{L}$ of CellTiter $96^{\circledR}$ Aqueous One Solution Reagent, and absorbance at $490 \mathrm{~nm}$ was determined with a microplate reader (Varioskan Flash; Thermo Fischer Scientific Inc., Waltham, MA, USA).

\subsection{Migration Assay for IFRS1 Cells}

The effects of Ex-4 on IFRS1 cell migration were evaluated by the scratch wound assay, as previously reported [18,49]. Briefly, the cells were seeded onto a poly-L-lysine (PL; Sigma, St. Louis, MO, USA, $10 \mu \mathrm{g} / \mathrm{mL}$ )-coated $35 \mathrm{~mm}$ glass-bottomed dish with grid (Matsunami Glass Ind., LTD, Osaka, Japan) at an approximate density of $2 \times 10^{4} / \mathrm{cm}^{2}$ and maintained in DMEM/5\%FBS for $24 \mathrm{~h}$. Then, a cell-free area was scratched using a sterile 200-microliter pipette tip (BM Equipment Co., Ltd., Tokyo, Japan). The cells were incubated in DMEM $/ 1 \%$ FBS with different concentrations $(0,10$, or $100 \mu \mathrm{M})$ of Ex-4, and the scratch was photographed 2 and $26 \mathrm{~h}$ after its generation using a phase-contrast light microscope (IMT-2; Olympus, Tokyo, Japan) equipped with a microscope digital camera system (DP22-CU; Olympus, Tokyo, Japan) and image analysis software (WinROOF2015; Mitani Corporation, Tokyo, Japan). The number of cells migrating into the square area of scratch $(6 \times 6$ grids $)$ during $24 \mathrm{~h}$ was calculated by reducing the number in the area at $26 \mathrm{~h}$ from that at $2 \mathrm{~h}$.

\subsection{In Vitro Myelination}

Myelinating co-culture of DRG neurons and IFRS1 cells was performed as previously reported [12] with slight modifications. Briefly, DRG neurons were seeded on type I collagen-coated 2-well chamber slides (Matsunami Glass Ind., LTD, Osaka, Japan) and Aclar fluorocarbon coverslips (Nissin EM Co., Tokyo, Japan) at an approximate density of $2 \times 10^{3} / \mathrm{cm}^{2}$ and maintained for 5-7 days in DMEM/F12 containing N2 supplement (Thermo Fisher Scientific Inc., Waltham, MA, USA), $10 \mathrm{ng} / \mathrm{mL}$ nerve growth factor (NGF; R\&D Systems, Inc., Minneapolis, MN, USA), $10 \mathrm{ng} / \mathrm{mL}$ glial cell line-derived neurotrophic factor (GDNF; R\&D Systems, Inc., Minneapolis, MN, USA), and $10 \mathrm{ng} / \mathrm{mL}$ ciliary neurotrophic factor (CNTF; PeproTech, Rocky Hill, NJ, USA). The cell density ratio of DRG neurons to IFRS1 cells was adjusted to 1:10. The co-cultured DRG neurons and IFRS1 cells were incubated for 2 days in DMEM/F12 supplemented with 5\% FBS and then maintained for up to 28 days in DMEM/F12 containing B27 supplement (Thermo Fisher Scientific Inc., Waltham, MA, USA), $50 \mathrm{\mu g} / \mathrm{mL}$ ascorbic acid (FUJIFILM Wako Pure Chemical Corp., Osaka, Japan), and different concentrations (0, 10, or $100 \mu \mathrm{M})$ of Ex-4.

\subsection{Reverse Transcription-Polymerase Chain Reaction (RT-PCR) for the Detection of GLP-1R $m R N A$}

Total RNA was isolated from the cultured cells using a RNeasy Mini Kit (Qiagen K.K., Tokyo, Japan). RT-PCR analysis was performed using the methods described in a previous paper [12], and the GoTaq Green Mater Mix (Promega Corp., Madison, WI, USA) and MiniOpticon (Bio-Rad Laboratories, Inc., Tokyo, Japan) were used according to the manufacturer's instructions. PCR was performed for $25-33$ cycles at $95{ }^{\circ} \mathrm{C}$ for $30 \mathrm{~s}, 55$ or $60{ }^{\circ} \mathrm{C}$ for $30 \mathrm{~s}$, and $72{ }^{\circ} \mathrm{C}$ for $30 \mathrm{~s}$. The sequences of oligonucleotide sense and antisense primers of GLP-1R and GAPDH (a house-keeping gene) for PCR are as follows:

GLP-1R, sense primer, $5^{\prime}$ - TATCTTCATCCGTGTCATCTGC $-3^{\prime}$ and antisense primer, 5'- AGCAGTACAGGATAGCCACCAT -3' (a 245-bp product); 
GAPDH, sense primer, $5^{\prime}$-TTCAACGGCACAGTCAAGGCTG-3' and antisense primer, 5'-TGGCATGGACTGTGGTCATGAG-3' (a 376-bp product).

The PCR products were separated by electrophoresis using a $2 \%$ agarose gel and visualized with ethidium bromide staining.

\subsection{Western Blot Analysis}

Western blot analysis was performed as previously described [18] with slight modifications. Briefly, protein was extracted from the cultured cells using $1 \times$ sodium dodecyl sulfate (SDS) sample buffer. The cell extracts were resolved using SDS-polyacrylamide gel electrophoresis (SDS-PAGE) in 5-20\% SDS-PAGE gel (FUJIFILM Wako Pure Chemical Corp., Osaka, Japan) and transferred onto a polyvinylidene fluoride membrane using an electroblotter (Nihon Eido Co., Ltd., Tokyo, Japan). The membrane was incubated in phosphate-buffered saline (PBS) with $0.1 \%$ Tween 20 (including $5 \%$ skimmed milk or 3\% bovine serum albumin) for $1 \mathrm{~h}$ at room temperature and then overnight at $4{ }^{\circ} \mathrm{C}$ with the following antibodies:

1. mouse anti-GLP-1R monoclonal antibody (1:1,000; Mab7F38, Developmental Studies Hybridoma Bank, Iowa City, USA) [19],

2. rabbit anti-AKT polyclonal antibody (1:1,000; Cell Signaling Technology, Beverly, MA, USA),

3. rabbit anti-phospho-AKT polyclonal antibody (1:1,000; Cell Signaling Technology, Beverly, MA, USA),

4. rabbit anti-myelin protein zero (MPZ) polyclonal antibody (1:1,000; a kind gift from Dr. Hitoshi Nagai, Mitsubishi Tanabe Pharma Corporation, Yokohama, Japan) [14],

5. rabbit anti-peripheral myelin protein 22 (PMP22) polyclonal antibody (1:1,000, Sigma, St. Louis, MO, USA) [50], and

6. mouse anti- $\beta$-tubulin isotype I+II monoclonal antibody (1:3,000; Sigma, St. Louis, MO, USA).

After rinsing with PBS, the membrane was incubated in a solution of horse radish peroxidase-conjugated anti-rabbit IgG antibody or anti-mouse IgG antibody (1:2000; MBL Corp., Ltd., Nagoya, Japan) for $1 \mathrm{~h}$. After rinsing, immunocomplexes on the membrane were visualized with ECL plus a Western Lighting Ultra (PerkinElmer, Inc., Waltham, MA, USA). Ez-Capture II chemiluminescence imaging system (Atto Corp, Tokyo, Japan) was used for quantitative analysis, and the relative signal intensity of PMP22/MPZ and phosphor-AKT was normalized to the intensity of $\beta$-tubulin I+II (Figure $5 \mathrm{~d}$ ) and AKT (Figure 5e), respectively.

\subsection{Immunofluorescence}

DRG neurons, IFRS1 cells, and their co-cultures were fixed with $4 \%$ paraformaldehyde for $10 \mathrm{~min}$ at $4{ }^{\circ} \mathrm{C}$ and then treated with $0.1 \%$ Triton X-100 in PBS for 5 min at room temperature. The cells were incubated overnight at $4{ }^{\circ} \mathrm{C}$ with the following antibodies diluted with $20 \mathrm{mM}$ PBS containing 0.4\% Block Ace (DS Pharma Biomedical Co., Osaka, Japan):

1. mouse anti-GLP-1R monoclonal antibody $(1: 1,000)[19]$,

2. rabbit anti-PMP22 polyclonal antibody $(1: 1,000)[50]$, and

3. mouse anti- $\beta$ III tubulin monoclonal antibody (1:1,000; Sigma, St. Louis, MO, USA) [51].

After rinsing with PBS, the cells were incubated for $1 \mathrm{~h}$ at $37^{\circ} \mathrm{C}$ with Alexa Fluor 488 anti-rabbit IgG antibody (1:200, Thermo Fisher) and/or Alexa Fluor 594 or 488 antimouse IgG antibody (1:200, Thermo Fisher) and then incubated with 4',6-diamidino-2phenylindole (DAPI; $300 \mathrm{nM}$, Thermo Fisher) for $5 \mathrm{~min}$ at room temperature. The samples processed for immunofluorescence were observed and recorded using a TCS SP5 confocal microscope system (Leica Microsystems, Wetzlar, Germany). Immunocytochemical controls in which the primary antibodies were omitted resulted in lack of positive staining on each culture sample (data not shown). Characterization and validation of these antibodies were described in the above articles. 


\subsection{Statistical Analysis}

All data were presented as means with standard deviation. The number of experiments is indicated in the figure legends. Parametric comparisons between experimental groups were performed by one-way analysis of variance (ANOVA); when ANOVA showed a significant difference between groups $(p<0.05)$, Tukey-Kramer test was used to identify which group differences accounted for the significant $p$ value.

Supplementary Materials: The following are available online at https:/ / www.mdpi.com/1422-006 7/22/6/2971/s1.

Author Contributions: Conceptualization, methodology, investigation, validation, formal analysis, writing - original draft preparation, S.T.; methodology, investigation, M.T., N.N., and H.Y.; conceptualization, supervision, project administration, writing — review and editing, K.S. All authors have read and agreed to the published version of the manuscript.

Funding: This research was funded by Grant-in-Aid for Scientific Research from the Ministry of Education, Culture, Science, Sports and Culture of Japan (JSPS KAKENHI 20K07027 and 20K07773 [April 1, 2020]) and was partly performed in the Cooperative Research Project Program of the Medical Institute of Bioregulation, Kyushu University [May 7, 2020].

Institutional Review Board Statement: The present study was conducted according to the guidelines of the Declaration of Helsinki, and approved by the Institutional Review Board of Tokyo Metropolitan Institute of Medical Science (institutional approval number 20-007 and 20-016, 2020).

Informed Consent Statement: Not applicable.

Data Availability Statement: The data presented in this study are available on request from the corresponding author.

Acknowledgments: We would like to thank Kazuhiko Watabe for providing us NSC-34 cells; Atsufumi Kawabata and Fumiko Sekiguchi for providing us ND7/23 cells; Masanari Itokawa and Izumi Nohara for technical advice on RT-PCR analysis; and Kazunori Utsunomiya, Koichi Kato, Junji Yamauchi, Tsutomu Nakahara, Mari Suzuki and Tomoyo Akamine for helpful comments on this study.

Conflicts of Interest: The authors declare no conflict of interest.

\section{Abbreviations}

$\begin{array}{ll}\text { AKT } & \text { Serine/threonine-specific protein kinase } \\ \text { CNTF } & \text { Ciliary neurotrophic factor } \\ \text { DAPI } & \text { 4',6-Diamidino-2-phenylindole } \\ \text { DMEM } & \text { Dulbecco's Modified Eagle's medium } \\ \text { DPP-4 } & \text { Dipeptidyl peptidase type 4 } \\ \text { DRG } & \text { Dorsal root ganglia } \\ \text { DPN } & \text { Diabetic peripheral neuropathy } \\ \text { ERK } & \text { Extracellular signal-regulated kinase } \\ \text { EX-4 } & \text { Exendin-4 } \\ \text { FBS } & \text { Fetal bovine serum } \\ \text { GDNF } & \text { Glial cell line-derived neurotrophic factor } \\ \text { GLP-1 } & \text { Glucagon-like peptide 1 } \\ \text { GLP-1R } & \text { GLP-1 receptor } \\ \text { GSK3 } & \text { glycogen synthase kinase 3 } \\ \text { IFRS1 } & \text { Immortalized Fischer 344 rat Schwann cell 1 } \\ \text { JAK } & \text { Janus kinase } \\ \text { MEK } & \text { Mitogen-activated kinase kinase } \\ \text { MPZ } & \text { Myelin protein zero } \\ \text { mTOR } & \text { mechanistic target of rapamycin } \\ \text { MTS } & \text { 3-(4,5-dimethylthiazol-2-yl)-5-(3carboxymethoxyphenyl)-2-(4-sulfophenyl)- }\end{array}$




$\begin{array}{ll}\text { NGF } & \text { Nerve growth factor } \\ \text { PI3K } & \text { Phosphatidyl inositol-3'-phosphate-kinase } \\ \text { PL } & \text { Poly-L-lysine } \\ \text { PMP22 } & \text { Peripheral myelin protein 22 } \\ \text { RhoA } & \text { Ras homolog family member A } \\ \text { SDS } & \text { Sodium dodecyl sulfate } \\ \text { STAT } & \text { signal transduction and activator of transcription } \\ \text { STZ } & \text { Streptozotocin }\end{array}$

\section{References}

1. Campbell, J.E.; Drucker, D.J. Pharmacology, Physiology, and Mechanisms of Incretin Hormone Action. Cell Metab. 2013, 17, 819-837. [CrossRef] [PubMed]

2. Htike, Z.Z.; Zaccardi, F.; Papamargaritis, D.; Webb, D.R.; Khunti, K.; Davies, M.J. Efficacy and safety of glucagon-like peptide-1 receptor agonists in type 2 diabetes: A systematic review and mixed-treatment comparison analysis. Diabetes Obes. Metab. 2017, 19, 524-536. [CrossRef]

3. Pyke, C.; Heller, R.S.; Kirk, R.K.; Ørskov, C.; Reedtz-Runge, S.; Kaastrup, P.; Hvelplund, A.; Bardram, L.; Calatayud, D.; Knudsen, L.B. GLP-1 Receptor Localization in Monkey and Human Tissue: Novel Distribution Revealed With Extensively Validated Monoclonal Antibody. Endocrinology 2014, 155, 1280-1290. [CrossRef] [PubMed]

4. Hölscher, C. Central effects of GLP-1: New opportunities for treatments of neurodegenerative diseases. J. Endocrinol. 2013, 221, T31-T41. [CrossRef]

5. Athauda, D.; Maclagan, K.; Skene, S.S.; Bajwa-Joseph, M.; Letchford, D.; Chowdhury, K.; Hibbert, S.; Budnik, N.; Zampedri, L.; Dickson, J.; et al. Exenatide once weekly versus placebo in Parkinson's disease: A randomised, double-blind, placebo-controlled trial. Lancet 2017, 390, 1664-1675. [CrossRef]

6. Liu, W.J.; Jin, H.Y.; Lee, K.A.; Xie, S.H.; Baek, H.S.; Park, T.S. Neuroprotective effect of the glucagon-like peptide-1 receptor agonist, synthetic exendin-4, in streptozotocin-induced diabetic rats. Br. J. Pharmacol. 2011, 164, 1410-1420. [CrossRef]

7. Yamamoto, K.; Amako, M.; Yamamoto, Y.; Tsuchihara, T.; Nukada, H.; Yoshihara, Y.; Arino, H.; Fujita, M.; Uenoyama, M.; Tachibana, S.; et al. Therapeutic Effect of Exendin-4, a Long-Acting Analogue of Glucagon-Like Peptide-1 Receptor Agonist, on Nerve Regeneration after the Crush Nerve Injury. BioMed. Res. Int. 2013, 2013, 1-7. [CrossRef] [PubMed]

8. Fujita, S.; Ushio, S.; Ozawa, N.; Masuguchi, K.; Kawashiri, T.; Oishi, R.; Egashira, N. Exenatide Facilitates Recovery from Oxaliplatin-Induced Peripheral Neuropathy in Rats. PLoS ONE 2015, 10, e0141921. [CrossRef]

9. Himeno, T.; Kamiya, H.; Naruse, K.; Harada, N.; Ozaki, N.; Seino, Y.; Shibata, T.; Kondo, M.; Kato, J.; Okawa, T.; et al. Beneficial Effects of Exendin-4 on Experimental Polyneuropathy in Diabetic Mice. Diabetes 2011, 60, 2397-2406. [CrossRef] [PubMed]

10. Tsukamoto, M.; Niimi, N.; Sango, K.; Takaku, S.; Kanazawa, Y.; Utsunomiya, K. Neurotrophic and neuroprotective properties of exendin-4 in adult rat dorsal root ganglion neurons: Involvement of insulin and RhoA. Histochem. Cell Biol. 2015, 144, 249-259. [CrossRef] [PubMed]

11. Hu, J.; Zhang, G.; Rodemer, W.; Jin, L.-Q.; Shifman, M.; Selzer, M.E. The role of RhoA in retrograde neuronal death and axon regeneration after spinal cord injury. Neurobiol. Dis. 2017, 98, 25-35. [CrossRef] [PubMed]

12. Sango, K.; Yanagisawa, H.; Kawakami, E.; Takaku, S.; Ajiki, K.; Watabe, K. Spontaneously immortalized Schwann cells from adult Fischer rat as a valuable tool for exploring neuron-Schwann cell interactions. J. Neurosci. Res. 2011, 89, 898-908. [CrossRef] [PubMed]

13. Sango, K.; Tsukamoto, M.; Utsunomiya, K.; Watabe, K. Spontaneously Immortalized Adult Rodent Schwann Cells as Valuable Tools for the Study of Peripheral Nerve Degeneration and Regeneration. In Schwann Cell Development and Pathology; Springer International Publishing: New York, NY, USA, 2014; pp. 147-170.

14. Sango, K.; Kawakami, E.; Yanagisawa, H.; Takaku, S.; Tsukamoto, M.; Utsunomiya, K.; Watabe, K. Myelination in coculture of established neuronal and Schwann cell lines. Histochem. Cell Biol. 2012, 137, 829-839. [CrossRef]

15. Cashman, N.R.; Durham, H.D.; Blusztajn, J.K.; Oda, K.; Tabira, T.; Shaw, I.T.; Dahrougr, S.; Antel, J.P. Neuroblastoma x spinal cord (NSC) hybrid cell lines resemble developing motor neurons. Dev. Dyn. 1992, 194, 209-221. [CrossRef]

16. Takaku, S.; Yako, H.; Niimi, N.; Akamine, T.; Kawanami, D.; Utsunomiya, K.; Sango, K. Establishment of a myelinating co-culture system with a motor neuron-like cell line NSC-34 and an adult rat Schwann cell line IFRS1. Histochem. Cell Biol. 2018, 149, 537-543. [CrossRef]

17. Wood, J.N.; Bevan, S.J.; Coote, P.R.; Dunn, P.M.; Harmar, A.; Hogan, P.; Latchman, D.S.; Morrison, C.; Rougon, G.; Theveniau, M.; et al. Novel cell lines display properties of nociceptive sensory neurons. Proc. R. Soc. B Boil. Sci. 1990, 241, 187-194. [CrossRef]

18. Takaku, S.; Sango, K. Zonisamide enhances neurite outgrowth from adult rat dorsal root ganglion neurons, but not proliferation or migration of Schwann cells. Histochem. Cell Biol. 2020, 153, 177-184. [CrossRef] [PubMed]

19. Albrechtsen, N.J.W.; Albrechtsen, R.; Bremholm, L.; Svendsen, B.; Kuhre, R.E.; Poulsen, S.S.; Christiansen, C.B.; Jensen, E.P.; Janus, C.; Hilsted, L.; et al. Glucagon-like Peptide 1 Receptor Signaling in Acinar Cells Causes Growth-Dependent Release of Pancreatic Enzymes. Cell Rep. 2016, 17, 2845-2856. [CrossRef] 
20. Haberberger, R.V.; Barry, C.; Matusica, D. Immortalized Dorsal Root Ganglion Neuron Cell Lines. Front. Cell. Neurosci. 2020, 14, 184. [CrossRef] [PubMed]

21. Mohiuddin, M.S.; Himeno, T.; Inoue, R.; Miura-Yura, E.; Yamada, Y.; Nakai-Shimoda, H.; Asano, S.; Kato, M.; Motegi, M.; Kondo, M.; et al. Glucagon-Like Peptide-1 Receptor Agonist Protects Dorsal Root Ganglion Neurons against Oxidative Insult. J. Diabetes Res. 2019, 2019, 1-10. [CrossRef]

22. Niimi, N.; Yako, H.; Tsukamoto, M.; Takaku, S.; Yamauchi, J.; Kawakami, E.; Yanagisawa, H.; Watabe, K.; Utsunomiya, K.; Sango, K. Involvement of oxidative stress and impaired lysosomal degradation in amiodarone-induced schwannopathy. Eur. J. Neurosci. 2016, 44, 1723-1733. [CrossRef]

23. Sango, K.; Saito, H.; Takano, M.; Tokashiki, A.; Inoue, S.; Horie, H. Cultured adult animal neurons and schwann cells give us new insights into diabetic neuropathy. Curr. Diabetes Rev. 2006, 2, 169-183. [CrossRef] [PubMed]

24. Suzuki, T.; Mizuno, K.; Yashima, S.; Watanabe, K.; Taniko, K.; Yabe-Nishimura, C. Characterization of polyol pathway in Schwann cells isolated from adult rat sciatic nerves. J. Neurosci. Res. 1999, 57, 495-503. [CrossRef]

25. Pan, B.; Huo, T.; Hu, Y.; Cao, M.; Bu, X.; Li, Z.; Jing, L.; Luo, X.; Gao, X.; Feng, H.; et al. Exendin-4 Promotes Schwann Cell Proliferation and Migration via Activating the Jak-STAT Pathway after Peripheral Nerve Injury. Neuroscience 2020, 437, 1-10. [CrossRef] [PubMed]

26. Niimi, N.; Yako, H.; Takaku, S.; Kato, H.; Matsumoto, T.; Nishito, Y.; Watabe, K.; Ogasawara, S.; Mizukami, H.; Yagihashi, S.; et al. A spontaneously immortalized Schwann cell line from aldose reductase-deficient mice as a useful tool for studying polyol pathway and aldehyde metabolism. J. Neurochem. 2018, 144, 710-722. [CrossRef]

27. De Vries, G.H.; Boullerne, A.I. Glial Cell Lines: An Overview. Neurochem. Res. 2010, 35, 1978-2000. [CrossRef]

28. Xie, Z.; Enkhjargal, B.; Wu, L.; Zhou, K.; Sun, C.; Hu, X.; Gospodarev, V.; Tang, J.; You, C.; Zhang, J.H. Exendin-4 attenuates neuronal death via GLP-1R/PI3K/Akt pathway in early brain injury after subarachnoid hemorrhage in rats. Neuropharmacol. 2018, 128, 142-151. [CrossRef]

29. Kimura, R.; Okouchi, M.; Fujioka, H.; Ichiyanagi, A.; Ryuge, F.; Mizuno, T.; Imaeda, K.; Okayama, N.; Kamiya, Y.; Asai, K.; et al. Glucagon-like peptide-1 (GLP-1) protects against methylglyoxal-induced PC12 cell apoptosis through the $\mathrm{PI} 3 \mathrm{~K} / \mathrm{Akt} / \mathrm{mTOR} / \mathrm{GCLc} /$ redox signaling pathway. Neuroscience 2009, 162, 1212-1219. [CrossRef]

30. Liu, X.-Y.; Wang, L.-X.; Chen, Z.; Liu, L.-B. Liraglutide prevents beta-amyloid-induced neurotoxicity in SH-SY5Y cells via a PI3K-dependent signaling pathway. Neurol. Res. 2016, 38, 313-319. [CrossRef] [PubMed]

31. Zhao, F.; Li, J.; Wang, R.; Xu, H.; Ma, K.; Kong, X.; Sun, Z.; Niu, X.; Jiang, J.; Liu, B.; et al. Exendin-4 promotes actin cytoskeleton rearrangement and protects cells from Nogo-A- $\Delta 20$ mediated spreading inhibition and growth cone collapse by down-regulating RhoA expression and activation via the PI3K pathway. Biomed. Pharmacother. 2019, 109, 135-143. [CrossRef]

32. Kalpachidou, T.; Spiecker, L.; Kress, M.; Quarta, S. Rho GTPases in the Physiology and Pathophysiology of Peripheral Sensory Neurons. Cells 2019, 8, 591. [CrossRef] [PubMed]

33. Candeias, E.; Sebastião, I.; Cardoso, S.; Carvalho, C.; Santos, M.S.; Oliveira, C.R.; Moreira, P.I.; Duarte, A.I. Brain GLP-1/IGF-1 Signaling and Autophagy Mediate Exendin-4 Protection Against Apoptosis in Type 2 Diabetic Rats. Mol. Neurobiol. 2018, 55, 4030-4050. [CrossRef]

34. Zhou, M.; Chen, S.; Peng, P.; Gu, Z.; Yu, J.; Zhao, G.; Deng, Y. Dulaglutide ameliorates STZ induced AD-like impairment of learning and memory ability by modulating hyperphosphorylation of tau and NFs through GSK3 $\beta$. Biochem. Biophys. Res. Commun. 2019, 511, 154-160. [CrossRef] [PubMed]

35. Lv, J.; Sun, X.; Ma, J.; Ma, X.; Zhang, Y.; Li, F.; Li, Y.; Zhao, Z. Netrin-1 induces the migration of Schwann cells via p38 MAPK and PI3K-Akt signaling pathway mediated by the UNC5B receptor. Biochem. Biophys. Res. Commun. 2015, 464, 263-268. [CrossRef] [PubMed]

36. Liu, H.-W.; Bi, W.-T.; Huang, H.-T.; Li, R.-X.; Xi, Q.; Feng, L.; Bo, W.; Hu, M.; Wen, W.-S. Satb1 promotes Schwann cell viability and migration via activation of PI3K/AKT pathway. Eur. Rev. Med. Pharmacol. Sci. 2018, 22, 4268-4277.

37. Gao, D.; Tang, T.; Zhu, J.; Tang, Y.; Sun, H.; Li, S. CXCL12 has therapeutic value in facial nerve injury and promotes Schwann cells autophagy and migration via PI3K-AKT-mTOR signal pathway. Int. J. Biol. Macromol. 2019, 124, 460-468. [CrossRef]

38. O'Brien, R.; Buckley, M.M.; Kelliher, A.; O'Malley, D. PI 3-kinase- and ERK-MAPK-dependent mechanisms underlie GlucagonLike Peptide-1-mediated activation of Sprague Dawley colonic myenteric neurons. Neurogastroenterol. Motil. 2019, 31 , e13631. [CrossRef]

39. Sango, K.; Yanagisawa, H.; Komuta, Y.; Si, Y.; Kawano, H. Neuroprotective properties of ciliary neurotrophic factor for cultured adult rat dorsal root ganglion neurons. Histochem. Cell Biol. 2008, 130, 669-679. [CrossRef]

40. Ogata, T.; Iijima, S.; Hoshikawa, S.; Miura, T.; Yamamoto, S.-I.; Oda, H.; Nakamura, K.; Tanaka, S. Opposing Extracellular Signal-Regulated Kinase and Akt Pathways Control Schwann Cell Myelination. J. Neurosci. 2004, 24, 6724-6732. [CrossRef]

41. Syed, N.; Reddy, K.; Yang, D.P.; Taveggia, C.; Salzer, J.L.; Maurel, P.; Kim, H.A. Soluble Neuregulin-1 Has Bifunctional, Concentration-Dependent Effects on Schwann Cell Myelination. J. Neurosci. 2010, 30, 6122-6131. [CrossRef]

42. Sango, K.; Mizukami, H.; Horie, H.; Yagihashi, S. Impaired Axonal Regeneration in Diabetes. Perspective on the Underlying Mechanism from In Vivo and In Vitro Experimental Studies. Front. Endocrinol. 2017, 8, 12. [CrossRef]

43. Shekunova, E.V.; Kashkin, V.A.; Muzhikyan, A.A.; Makarova, M.N.; Balabanyan, V.Y.; Makarov, V.G. Therapeutic efficacy of arginine-rich exenatide on diabetic neuropathy in rats. Eur. J. Pharmacol. 2020, 866, 172835. [CrossRef] [PubMed] 
44. Yasuda, H.; Terada, M.; Maeda, K.; Kogawa, S.; Sanada, M.; Haneda, M.; Kashiwagi, A.; Kikkawa, R. Diabetic neuropathy and nerve regeneration. Prog. Neurobiol. 2003, 69, 229-285. [CrossRef]

45. Bezdjian, A.; Kraaijenga, V.J.C.; Ramekers, D.; Versnel, H.; Thomeer, H.G.X.M.; Klis, S.F.L.; Grolman, W. Towards Clinical Application of Neurotrophic Factors to the Auditory Nerve; Assessment of Safety and Efficacy by a Systematic Review of Neurotrophic Treatments in Humans. Int. J. Mol. Sci. 2016, 17, 1981. [CrossRef]

46. Glotfelty, E.J.; Olson, L.; Karlsson, T.E.; Li, Y.; Greig, N.H. Glucagon-like peptide-1 (GLP-1)-based receptor agonists as a treatment for Parkinson's disease. Expert Opin. Investig. Drugs 2020, 29, 595-602. [CrossRef] [PubMed]

47. Jaiswal, M.; Martin, C.L.; Brown, M.B.; Callaghan, B.; Albers, J.W.; Feldman, E.L.; Pop-Busui, R. Effects of exenatide on measures of diabetic neuropathy in subjects with type 2 diabetes: Results from an 18-month proof-of-concept open-label randomized study. J. Diabetes Its Complicat. 2015, 29, 1287-1294. [CrossRef]

48. Brock, C.; Hansen, C.S.; Karmisholt, J.; Møller, H.J.; Juhl, A.; Farmer, A.D.; Drewes, A.M.; Riahi, S.; Lervang, H.H.; Jakobsen, P.E.; et al. Liraglutide treatment reduced interleukin- 6 in adults with type 1 diabetes but did not improve established autonomic or polyneuropathy. Br. J. Clin. Pharmacol. 2019, 85, 2512-2523. [CrossRef]

49. Roloff, F.; Ziege, S.; Baumgärtner, W.; Wewetzer, K.; Bicker, G. Schwann cell-free adult canine olfactory ensheathing cell preparations from olfactory bulb and mucosa display differential migratory and neurite growth-promoting properties in vitro. BMC Neurosci. 2013, 14, 141. [CrossRef]

50. Roa, B.B.; Dyck, P.J.; Marks, H.G.; Chance, P.F.; Lupski, J.R. Dejerine-Sottas syndrome associated with point mutation in the peripheral myelin protein 22 (PMP22) gene. Nat. Genet. 1993, 5, 269-273. [CrossRef]

51. Vent, J.; Wyatt, T.A.; Smith, D.D.; Banerjee, A.; Ludueña, R.F.; Sisson, J.H.; Hallworth, R. Direct involvement of the isotype-specific C-terminus of beta tubulin in ciliary beating. J. Cell Sci. 2005, 118, 4333-4341. [CrossRef] 